University of Nebraska - Lincoln

DigitalCommons@University of Nebraska - Lincoln

\title{
$5-2012$
}

\section{Remote estimation of crop gross primary production with Landsat data}

Anatoly Gitelson

University of Nebraska-Lincoln, agitelson2@unl.edu

Yi Peng

University of Nebraska-Lincoln, ypeng2@unl.edu

Jeffrey G. Masek

NASA Goddard Space Flight Center, Greenbelt, MD, jeffrey.g.masek@nasa.gov

Donald Rundquist

University of Nebraska - Lincoln, drundquist1@unl.edu

Shashi Verma

University of Nebraska - Lincoln, sverma1@unl.edu

See next page for additional authors

Follow this and additional works at: https://digitalcommons.unl.edu/natrespapers

Part of the Natural Resources and Conservation Commons

Gitelson, Anatoly; Peng, Yi; Masek, Jeffrey G.; Rundquist, Donald; Verma, Shashi; Suyker, Andrew E.; Baker, John M.; and Meyers, Tilden, "Remote estimation of crop gross primary production with Landsat data" (2012). Papers in Natural Resources. 318.

https://digitalcommons.unl.edu/natrespapers/318

This Article is brought to you for free and open access by the Natural Resources, School of at DigitalCommons@University of Nebraska - Lincoln. It has been accepted for inclusion in Papers in Natural Resources by an authorized administrator of DigitalCommons@University of Nebraska - Lincoln. 


\section{Authors}

Anatoly Gitelson, Yi Peng, Jeffrey G. Masek, Donald Rundquist, Shashi Verma, Andrew E. Suyker, John M. Baker, and Tilden Meyers 


\title{
Remote estimation of crop gross primary production with Landsat data
}

\author{
Anatoly A. Gitelson ${ }^{\text {a,* }}$, Yi Peng ${ }^{\text {a }}$, Jeffery G. Masek ${ }^{\mathrm{b}}$, Donald C. Rundquist ${ }^{\mathrm{a}}$, Shashi Verma ${ }^{\mathrm{a}}$, Andrew Suyker ${ }^{\mathrm{a}}$, \\ John M. Baker ${ }^{c}$, Jerry L. Hatfield ${ }^{\mathrm{d}}$, Tilden Meyers ${ }^{\mathrm{e}}$ \\ a School of Natural Resources, University of Nebraska-Lincoln, Lincoln, NE, USA \\ ${ }^{\mathrm{b}}$ NASA Goddard Space Flight Center, Greenbelt, MD, USA \\ c Soil and Water Management Research Unit, USDA, MN, USA \\ d National Laboratory for Agriculture and the Environment, USDA, Ames, IA, USA \\ e National Oceanic and Atmospheric Administration, Oak Ridge, TN, USA
}

\section{A R T I C L E I N F O}

\section{Article history:}

Received 20 December 2011

Received in revised form 17 February 2012

Accepted 18 February 2012

Available online 22 March 2012

\section{Keywords:}

Gross primary production

Landsat

Chlorophyll content

Vegetation index

Potential incident photosynthetically active radiation

\begin{abstract}
A B S T R A C T
An accurate and synoptic quantification of gross primary production (GPP) in crops is essential for studies of carbon budgets at regional and global scales. In this study, we tested a model, relating crop GPP to a product of total canopy chlorophyll $(\mathrm{Chl})$ content and potential incident photosynthetically active radiation ( $\left.\mathrm{PAR}_{\text {potential }}\right)$. The approach is based on remotely sensed data; specifically, vegetation indices (VI) that are proxies for total Chl content and $\mathrm{PAR}_{\text {potential, }}$, which is incident PAR under a condition of minimal atmospheric aerosol loading. Using VI retrieved from surface reflectance Landsat data, we found that the model is capable of accurately estimating GPP in maize, with coefficient of variation (CV) below $23 \%$, and in soybean with CV below $30 \%$. The algorithms established and calibrated over three Mead, Nebraska AmeriFlux sites were able to estimate maize and soybean GPP at tower flux sites in Minnesota, Iowa and Illinois with acceptable accuracy.
\end{abstract}

(c) 2012 Elsevier Inc. All rights reserved.

\section{Introduction}

Currently approximately $24 \%$ of the Earth's land surface is cultivated cropland (Cassman \& Wood, 2005). Croplands are both a unique resource and the product of a vital human activity, not only because of a need to feed the world's seven billion people, but also because crops impact environmental processes such as global carbon cycling and climate change (Cassman \& Wood, 2005; Malmstrom et al., 1997). Gross primary productivity (GPP) is the rate at which vegetation captures and stores carbon as biomass, and GPP can potentially be used for estimating crop yield as well as calculating carbon budgets (Malmstrom et al., 1997; Reeves et al., 2004). An accurate and synoptic quantification of spatially distributed GPP is essential for monitoring both crop status and carbon exchange.

Crop productivity is a result of the interception of solar radiation by the vegetation canopy. Thus, it is possible to use remotely sensed data from satellites, including reflected and emitted radiation from Earth in various wavelengths of the electromagnetic spectrum, as a powerful and expedient tool for assessing crop GPP at regional and global scales. Since 1999, the National Aeronautics and Space Administration (NASA) has provided GPP estimates for the entire globe based on the Moderate Resolution Imaging Spectroradiometer (MODIS) $1 \mathrm{~km}$

\footnotetext{
* Corresponding author. Tel.: + 14024728386.

E-mail address: agitelson2@unl.edu (A.A. Gitelson).
}

products (e.g., Running, et al., 2000; Running et al., 2004). The current MODIS GPP algorithm provides reasonable spatial patterns and logical temporal variability across a diverse range of biomes and climate regimes. However, continued efforts are needed to resolve significant problems in certain biomes, especially in croplands, where an accurate MODIS estimation of GPP is still elusive (e.g., Heinsch et al., 2006; Turner et al., 2005, 2006). A recent evaluation of satellite-based MODIS products revealed that the estimates of GPP and net primary production (NPP) were particularly poor for maize and soybean test sites (Turner et al., 2005). Even though the annual NPP for the maize and soybean fields was among the most accurate available ancillary data of all biomes studied, the uncertainties of the MODIS-derived estimates for the agricultural sites were the highest; the MODIS product strongly underestimated NPP. There are several reasons for the poor performance of the MODIS product for croplands (e.g., Heinsch et al., 2006; Sims et al., 2006; Turner et al., 2005; Zhao et al., 2005). The reasons include: (a) the use of a constant maximum light use efficiency (LUE) value within a given biome, a consequence of which is a reduced ability to detect differences in species-specific LUE among crops (e.g., $C_{3}$ vs. $C_{4}$ ); (b) the assumption of a single land cover class for the entire $1 \mathrm{~km}$ pixel even though there is a considerable discrepancy between the spatial resolution of the MODIS product $(1 \mathrm{~km})$ and typical smaller sizes of cropped fields in North America; and (c) the use of a generalized radiation transfer algorithm for the retrieval of fraction of absorbed photosynthetically active radiation (fAPAR) based on leaf area index (LAI, Myneni et al., 1997) without a site-specific approach to characterize the vegetation 
species. Different crops with the same LAI (e.g., soybean vs. maize: Suyker et al., 2005) have very different GPP values.

Potential alternatives to MODIS are the Landsat Thematic Mapper (TM) and Landsat Enhanced Thematic Mapper (ETM) sensors, with their fine spatial resolution (30 $\mathrm{m}$ pixel). Landsat data may provide useful information to facilitate the analysis of $\mathrm{CO}_{2}$ exchange in croplands. Ecophysiological differences between and among different crop species are well documented, so classification of crop types using the Landsat data should be particularly useful. Due to differences in canopy architectures and leaf structures, LUE varies drastically between species ( $C_{3}$ vs. $C_{4}$ crops: maize LUE is nearly double that of soybean - e.g., Suyker et al., 2005), causing great uncertainties in estimating $\mathrm{CO}_{2}$ fluxes in crops with the coarse spatial resolution $(1 \mathrm{~km})$ of MODIS. The use of TM and ETM data allows one the opportunity to overcome these limitations. With the opening of the Landsat archives to free and web-based access, the use of the sensor data with greatly improved spatial resolution may considerably reduce the uncertainties of GPP estimation in crops.

The overall goal of our study is to develop, calibrate and validate a model for accurate estimation of gross primary production in maizesoybean croplands based on Landsat data.

\section{Methodology}

The estimation of crop productivity is based on a concept originally developed by Monteith $(1972,1977)$, who suggested that GPP is related to the product of the fraction of radiation absorbed by photo-

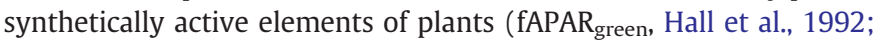
Viña and Gitelson, 2005), the incident photosynthetically active radiation $\left(\mathrm{PAR}_{\mathrm{in}}\right)$, and the efficiency of the absorbed radiation being converted into biomass (LUE):

$\mathrm{GPP}_{\mathrm{f} f \mathrm{APAR}}$ green $\times \mathrm{PAR}_{\text {in }} \times \mathrm{LUE}$.

It is recognized that the two key physiological properties of photosynthesis in Eq. (1), fAPAR green and LUE, relate closely to total canopy chlorophyll (Chl) content (Baret et al., 2007; Houborg et al., 2011; Peng et al., 2011). Total canopy Chl content, defined as a product of total leaf area and leaf Chl content (Gitelson et al., 2003), seems to be the most relevant community property of vegetation productivity (Whittaker \& Marks, 1975). Total Chl content strongly correlates with light absorption (Lieth \& Whittaker, 1975) and directly relates the enhanced electron transport activity, which governs LUE (Terry, 1980), to plant stress. Close relationships between GPP and the product of total Chl content and $\mathrm{PAR}_{\text {in }}$ have been documented in three contrasting crop types: maize, soybean and wheat (Gitelson et al., 2003; Gitelson et al., 2006; Wu et al., 2009). Consequently, a model was recently suggested to remotely estimate crop GPP via total Chl content and $\mathrm{PAR}_{\text {in }}$ (Gitelson et al., 2006):

$\mathrm{GPP} \propto \mathrm{Chl} \times \mathrm{PAR}_{\text {in }}$

Thus, to remotely estimate GPP in crops, one needs to retrieve an accurate measure of Chl content from remotely sensed data. Vegetation indices (VI), which are mathematical combinations of reflectance in two or more spectral bands, are widely used to quantitatively measure biophysical characteristics of vegetation (e.g., Jones \& Vaughan, 2011). Many approaches for accurately estimating the total Chl content using VI have been proposed. The Terrestrial Chlorophyll Index (MTCI) has been specifically proposed for Medium Resolution Imaging Spectrometer (MERIS) data to estimate total Chl content (Dash \& Curran, 2004). Green and red edge chlorophyll indices ( $\mathrm{Cl}_{\text {green }}$ and $\left.\mathrm{Cl}_{\text {red edge }}\right)$ were introduced and applied successfully for estimating total Chl content in maize and soybean (Gitelson et al., 2005). The $\mathrm{Cl}_{\text {green }}$, derived from Hyperion and Landsat-TM images, was found to be closely related to maize Chl content with a determination coefficient $\left(R^{2}\right)$ above 0.86
(Wu et al., 2010a, b). The Wide Dynamic Range Vegetation Index WDRVI (Gitelson, 2004), retrieved from the MODIS $250 \mathrm{~m}$ product, appeared to be a good proxy of green LAI (Gitelson et al., 2007), which closely relates to total Chl content (Ciganda et al., 2008). Thus, these chlorophyll-related VI can all be used as proxies of Chl content, and the model for GPP estimation has the form (Gitelson et al., 2006):

$\mathrm{GPP} \propto \mathrm{VI} \times \mathrm{PAR}_{\mathrm{in}}$

This model was capable of estimating crop GPP accurately using in situ reflectance transformed to simulate the spectral bands of MODIS and MERIS (Gitelson et al., 2006; Peng \& Gitelson, 2011a; Peng \& Gitelson, 2011b; Peng et al., 2011). The VI-PAR in -based model (Eq. 3), with MTCI derived from MERIS images, was capable of estimating GPP accurately across a variety of land cover and vegetation types (Almond et al., 2010; Harris \& Dash, 2010). Wu et al. (2010a, 2011) showed that maize GPP could be estimated with high accuracy using the VI-PAR in $^{-}$ based model with MODIS data. The VI-PAR in -based model was also accurate in estimating maize GPP using Landsat-ETM data (Gitelson et al., 2008). However, in all applications, discussed above, $P R_{\text {in }}$ measured at ground level with tower-based systems was used.

The temporal behavior of PAR $_{\text {in }}$ during the growing season includes two types of variation: low- and high-frequency variations (Fig. 1). The former is due to seasonally decreased $\mathrm{PAR}_{\text {in }}$ intensity; total hours of sunlight in the northern hemisphere gradually decrease after the summer solstice, which occurs around June 21 for Nebraska (day of year, DOY, 172). For example, the monthly-average incoming $P_{A R}$ in intensity in the Midwestern U.S. declined by $31 \%$ from July to September (Sakamoto et al., 2011). This significant decline of PAR $_{\text {in }}$ causes a decrease in crop productivity (Peng et al., 2011; Sakamoto et al., 2011). There is also high frequency $\mathrm{PAR}_{\text {in }}$ variation, which corresponds to short-period changes in atmospheric transmissivity due to clouds or aerosols (Peng et al., 2011).

During the growing season, crop GPP is affected by variation in total Chl content (Eq. 2), as well as low and high frequency variations of $\mathrm{PAR}_{\mathrm{in}}$. Chl-related VI closely follow seasonal changes in Chl content (Almond et al., 2010; Gitelson et al., 2005; Harris \& Dash, 2010; Wu et al., 2009). In the green-up stage, VI alone relate closely to GPP, while in reproductive and senescence stages, as $\mathrm{PAR}_{\text {in }}$ declines, discrepancies between VI and GPP increased (Peng et al., 2011; Sakamoto et al., 2011). The product of VI and PAR $_{\text {in }}$ relates more closely to GPP than does the VI alone because together they account for both the seasonal change in crop $\mathrm{Chl}$ and the modulation of GPP due to changes in radiation conditions (Almond et al., 2010; Peng et al., 2011; Sakamoto et al., 2011).

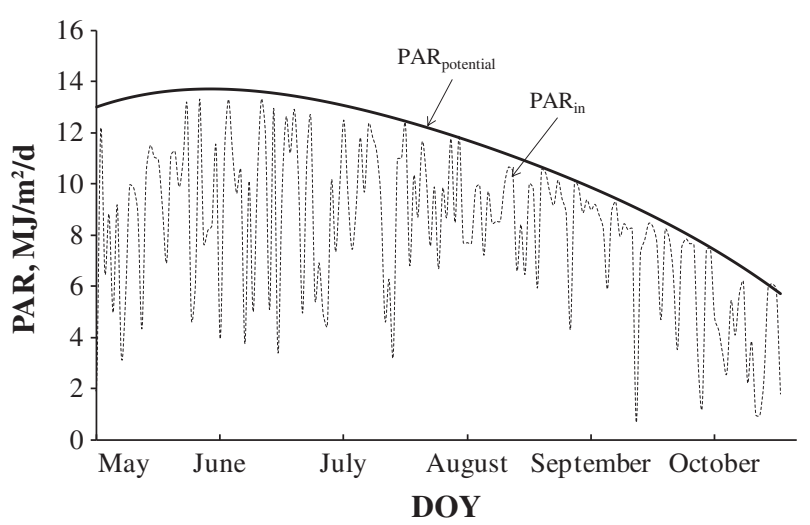

Fig. 1. Temporal behavior of $P A R_{i n}$ and $P A R_{\text {potential }}$ during the growing season, 2004

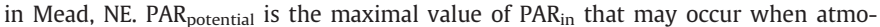
spheric gasses and aerosol concentrations are minimal. It represents the seasonal changes of sunshine duration (i.e. day length) but does not account for high frequency variations of incoming radiation related to daily weather conditions. 
To develop algorithms based solely on remotely sensed data, one needs to find an accurate proxy for $\mathrm{PAR}_{\text {in }}$ that can be measured remotely. Shortwave radiation (SW) obtained from coarse scale meteorological data sets from the NASA Data Assimilation Office was used as a substitute for $\mathrm{PAR}_{\text {in }}$ as input to Eq. (3) (Sakamoto et al., 2011). However, these estimates of $P R_{\text {in }}$ have significant uncertainties; the coefficient of variation (CV) was $23.6 \%$ and mean normalized bias (MNB) was 13.9\% (Sakamoto et al., 2011).

In the current study, we attempted to use the maximal value of $\mathrm{PAR}_{\text {in }}$ that may occur when the concentrations of atmospheric gasses and aerosols are minimal. We term this variable "potential incident photosynthetically active radiation” ( $\left.\mathrm{PAR}_{\text {potential }}\right)$ - Fig. 1 . PAR $\mathrm{Potential}$ represents the seasonal changes in hours of sunshine (i.e. day length). It may be calculated using the $6 \mathrm{~S}$ radiative transfer code (Kotchenova \& Vermote, 2007; Vermote et al., 1997b) for a "clean" (non-absorbing) aerosol model with an optical thickness of 0.05 at $550 \mathrm{~nm}$ and water vapor below $1 \mathrm{~g} / \mathrm{m}^{2}$. The solar irradiance at the top of the atmosphere (TOA), geographic coordinates and solar angle for a given location should be used as input data (Vermote, personal communi-

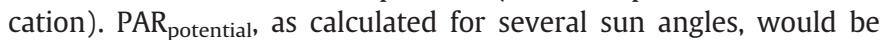
used to define a total daily value. Another way to find $\mathrm{PAR}_{\text {potential }}$ is using a look-up table (LUT)-based algorithm, providing $\mathrm{PAR}_{\text {in }}$ as a function of solar zenith angle, column water vapor and optical thickness for several different representative aerosol models (Lyapustin, personal communication). LUTs were generated using the interpolation and profile correction method (Lyapustin, 2003). For our purpose, $\mathrm{PAR}_{\text {potential }}$ will be obtained as a look-up table value for the background aerosol and a typical column water vapor.

Thus, we suggest using PAR $_{\text {potential }}$ as a proxy of $\mathrm{PAR}_{\text {in }}$ for the model:

$\mathrm{GPP} \propto \mathrm{VI} \times \mathrm{PAR}_{\text {potential }}$

The specific objectives of this study are (1) to compare the accuracy of Landsat based GPP estimation models for maize and soybean, using both PAR potential (Eq. 4) and $\mathrm{PAR}_{\text {in }}$ (Eq. 3), (2) to assess the accuracy and uncertainties of several Landsat-retrieved VI in estimating crop GPP, and (3) to explore the possibility of using a unified algorithm for GPP estimation in study sites that are different in geographic locations, crop management systems, and climatic conditions.

\section{Data and methods}

\subsection{Study sites}

Data from seven study sites were used in our investigation (Fig. 2), three of which are located at the University of Nebraska-Lincoln Agricultural Research and Development Center near Mead, Nebraska, USA (http://public.ornl.gov/ameriflux/Site_Info/siteInfo.cfm?KEYID=us. mead). Those three sites are all approximately 60-ha fields within $1.6 \mathrm{~km}$ of each other. Site 1 is planted in continuous maize equipped with a center pivot irrigation system. Sites 2 and 3 are both planted in maize-soybean rotation, but the former is irrigated in the same way as site 1 , while site 3 relies entirely on rainfall for moisture. In the Nebraska (NE) sites, the planting density for maize is around 75,000 plants per hectare and around 300,000 plants per hectare for soybean.

Site 4, near Rosemount, Minnesota (MN), is 18.4 ha in size (http:// public.ornl.gov/ameriflux/Site_Info/siteInfo.cfm?KEYID=us.rosemount. $01)$. Sites 5 and 6 are 60-ha fields, in close proximity, near Ames, Iowa (IA) (http://public.ornl.gov/ameriflux/Site_Info/siteInfo.cfm? KEYID). Site 7 is located at Bondville, Illinois (IL) (http://public.ornl. gov/ameriflux/Site_Info/siteInfo.cfm?KEYID=us.bondville.01). The four study sites in MN, IA and IL are all planted in rainfed maize-soybean rotation, and the planting density was 86,000 plants per ha for maize and 340,600 plants per ha for soybean. More details about the crop management and field history of these study sites are available in

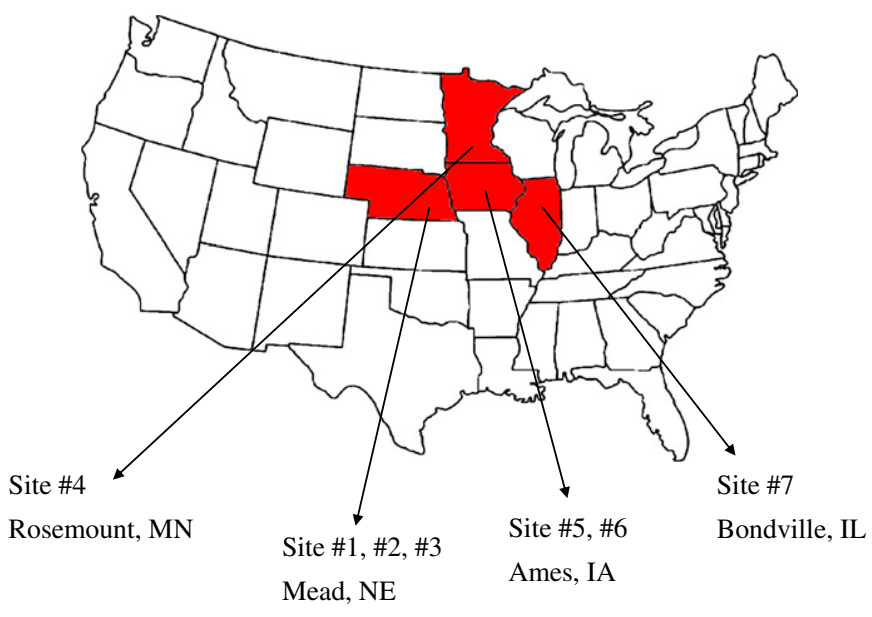

Fig. 2. The general location of the seven study sites in Minnesota, Nebraska, Iowa and Illinois.

Baker and Griffis (2005), Hatfield et al. (1999), Hollinger et al. (2005) and Verma et al. (2005).

Each study site is equipped with an eddy covariance tower and meteorological sensors to obtain continuous measurements of $\mathrm{CO}_{2}$ fluxes, water vapor and energy fluxes every hour (for example, see Verma et al., 2005). Daytime net ecosystem exchange (NEE) values were computed by integrating the hourly $\mathrm{CO}_{2}$ fluxes collected during a day when $\mathrm{PAR}_{\text {in }}$ exceeded $1 \mu \mathrm{mol} / \mathrm{m}^{2} / \mathrm{s}$. Daytime estimates of ecosystem respiration $(\mathrm{Re})$ were obtained from the night $\mathrm{CO}_{2}$ exchange-temperature relationship (e.g., Xu \& Baldocchi, 2003). The GPP was then obtained by subtracting Re. The GPP data used in this study were from NE sites during 2001-2008, from IL sites during 2001-2003, and from MN and IA sites during 2005-2007.

\subsection{Landsat data and Landsat-retrieved VI}

Both Landsat-5 TM and Landsat-7 ETM + images were used in order to maximize cloud-free imaging opportunities. The details about the images used in this study are given in Table 1. The Landsat data used as input in this study were standard L1t files (georegistered, orthorectified) from the US Geological Survey. The geodetic accuracy of the L1t product is typically within $30 \mathrm{~m}$ (Lee et al., 2004). The image digital numbers were converted to top-of-atmosphere (TOA) reflectances, and then atmospherically corrected to surface reflectance using the Landsat Ecosystem Disturbance Adaptive Processing System (LEDAPS) at NASA GSFC (Masek et al., 2006). The atmospheric correction procedure corrects for gaseous absorption, Rayleigh scattering, and Mie (aerosol) scattering using the MODIS/6S radiative transfer model (Vermote et al., 1997a). Ozone concentrations are derived from Total Ozone Mapping Spectrometer (TOMS) data aboard the Nimbus-7, Meteor-3, and Earth Probe platforms. Column water vapor was taken from NOAA National Centers for Environmental Prediction (NCEP) reanalysis data available at a resolution of $2.5^{\circ} \times 2.5^{\circ}$.

Aerosol optical thickness was derived for each image using the dark, dense vegetation approach of Kaufman et al. (1997). Based on the physical correlation between chlorophyll absorption and absorption by liquid water in vegetation, this method postulates a linear relation between shortwave-infrared $(2.2 \mu \mathrm{m})$ surface reflectance (nearly unaffected by the atmosphere) and surface reflectance in the visible bands. By using the relationship to calculate surface reflectance for the visible bands, and comparing the result to the TOA reflectance, aerosol optical depth may be estimated.

LEDAPS surface reflectance products have been compared to in situ data from the Aerosol Robotic Network (AERONET) and to daily 500 meter resolution surface reflectance products from the MODIS 
Table 1

Details regarding Landsat data acquisitions over seven study sites used in this analysis.

\begin{tabular}{|c|c|c|c|c|c|c|}
\hline $\begin{array}{l}\text { Site } \\
\#\end{array}$ & $\begin{array}{l}\text { Site location } \\
\text { (Ameriflux ID) }\end{array}$ & Coordinate & $\begin{array}{l}\text { Elevation } \\
(\mathrm{m})\end{array}$ & $\begin{array}{l}\text { Image } \\
\text { information }\end{array}$ & $\begin{array}{l}\text { Study } \\
\text { period }\end{array}$ & $\begin{array}{l}\text { Total } \\
\text { number of } \\
\text { images }\end{array}$ \\
\hline 1 & $\begin{array}{l}\text { Mead, NE } \\
\text { (US-Ne1) }\end{array}$ & $\begin{array}{l}41^{\circ} 09^{\prime} \\
54.2^{\prime \prime} \mathrm{N} \\
96^{\circ} 28^{\prime} \\
35.9^{\prime \prime} \mathrm{W}\end{array}$ & 361 & W2P028R031 & $01-08$ & 60 \\
\hline 2 & $\begin{array}{l}\text { Mead, NE } \\
\text { (US-Ne2) }\end{array}$ & $\begin{array}{l}41^{\circ} 09^{\prime} \\
53.5^{\prime \prime} \mathrm{N} \\
96^{\circ} 28^{\prime} \\
12.3^{\prime \prime} \mathrm{W}\end{array}$ & 362 & W2P028R031 & $01-08$ & 59 \\
\hline 3 & $\begin{array}{l}\text { Mead, NE } \\
\text { (US-Ne3) }\end{array}$ & $\begin{array}{l}41^{\circ} 10^{\prime} \\
46.8^{\prime \prime} \mathrm{N} \\
96^{\circ} 26^{\prime} \\
22.7^{\prime \prime} \mathrm{W}\end{array}$ & 363 & W2P028R031 & $01-08$ & 56 \\
\hline 4 & $\begin{array}{l}\text { Ames, IA } \\
\text { (US-Br1) }\end{array}$ & $\begin{array}{l}41^{\circ} 58^{\prime} \\
29.6^{\prime \prime} \mathrm{N} \\
93^{\circ} 41^{\prime} \\
25.4^{\prime \prime} \mathrm{W}\end{array}$ & 275 & $\begin{array}{l}\text { W2P026R031 } \\
\text { W2P027R031 }\end{array}$ & $05-07$ & 32 \\
\hline 5 & $\begin{array}{l}\text { Ames, IA } \\
\text { (US-Br3) }\end{array}$ & $\begin{array}{l}41^{\circ} 58^{\prime} \\
28.9^{\prime \prime} \mathrm{N} \\
93^{\circ} 41^{\prime} \\
37.0^{\prime \prime} \mathrm{W}\end{array}$ & 314 & $\begin{array}{l}\text { W2P026R031 } \\
\text { W2P027R031 }\end{array}$ & $05-07$ & 34 \\
\hline 6 & $\begin{array}{l}\text { Bondville, IL } \\
\text { (US-Bo1) }\end{array}$ & $\begin{array}{l}40^{\circ} 0^{\prime} 22.3^{\prime \prime} \\
\mathrm{N} \\
88^{\circ} 17^{\prime} \\
25.4^{\prime \prime} \mathrm{W}\end{array}$ & 219 & $\begin{array}{l}\text { W2P022R032 } \\
\text { W2P023R032 }\end{array}$ & 01-03 & 35 \\
\hline 7 & $\begin{array}{l}\text { Rosemount, } \\
\text { MN } \\
\text { (US-Ro1) }\end{array}$ & $\begin{array}{l}44^{\circ} 42^{\prime} \\
51.5^{\prime \prime} \mathrm{N} \\
93^{\circ} 05^{\prime} \\
23.4^{\prime \prime} \mathrm{W}\end{array}$ & 260 & W2P027R029 & $05-07$ & 16 \\
\hline
\end{tabular}

a) Maize

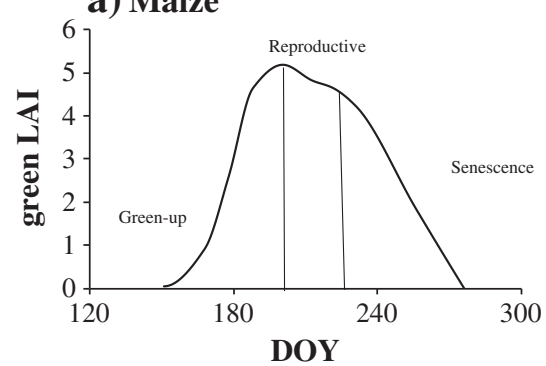

c) Maize site, $\mathrm{NE}$

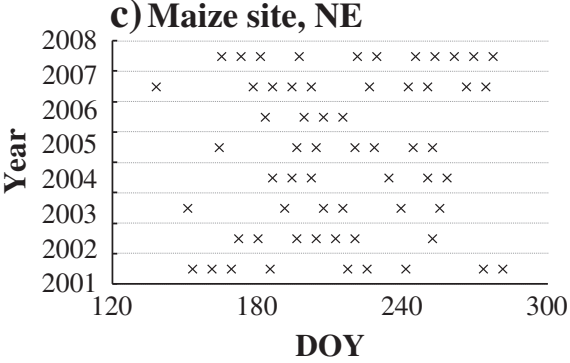

e) Maize site, MN, IA and IL

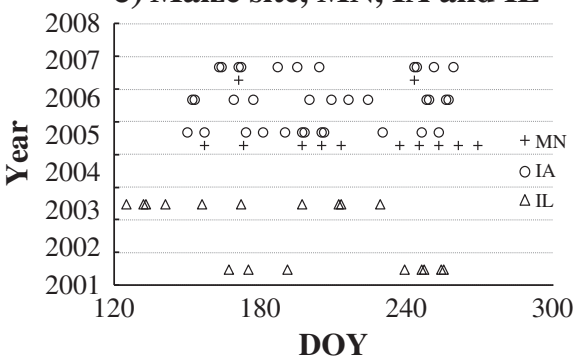

sensor aboard the NASA Terra spacecraft (Feng et al., 2011; Masek et al., 2006). The uncertainties associated with the calculated reflectance values appear to be within the uncertainty of the MODIS surface reflectance product (the greater of $0.5 \%$ absolute reflectance or $5 \%$ of the recorded reflectance value) for normal aerosol loadings $\left(\tau_{550 \mathrm{~nm}}<0.5\right)$.

For each study site, we defined a rectangle in the center of a Landsat image fitted in the field. The rectangle included 552 pixels $(690 \mathrm{~m} \times 720 \mathrm{~m})$ for site $1 \mathrm{NE}, 506$ pixels $(690 \mathrm{~m} \times 660 \mathrm{~m})$ for site $2 \mathrm{NE}$, 576 pixels $(720 \mathrm{~m} \times 720 \mathrm{~m})$ for site $3 \mathrm{NE}, 276$ pixels $(360 \mathrm{~m} \times 690 \mathrm{~m})$ for site $4 \mathrm{IA}, 325(390 \mathrm{~m} \times 750 \mathrm{~m})$ pixels for site $5 \mathrm{IA}, 132$ pixels $(330 \mathrm{~m} \times 360 \mathrm{~m})$ for site $6 \mathrm{IL}$, and 272 pixels $(480 \mathrm{~m} \times 510 \mathrm{~m})$ for site 7 MN. We applied the same rectangle to all images to extract the pixels of interest, and the reflectance values for study sites were calculated by averaging all the per-pixel values within the rectangle. A total of 290 Landsat-retrieved site spectral reflectances were paired with corresponding daytime GPP observations during our study period (Fig. 3). Fig. 3a and $b$ showed the dynamics of green LAI in maize and soybean during the growing season. In general, maize has a longer growth period than soybean, and the maximum green LAI of maize is about $25 \%$ higher than for soybean. For maize data, we compiled a total of 120 images for NE sites, 12 for MN sites, 38 for IA sites and 20 for IL sites. Compared to maize data, the number of images for soybean fields was limited. In total, we had 55 images for NE sites, 4 for MN sites, 28 for IA sites, and 15 for IL sites. The data from three NE study sites, which were representative of all phenological stages found in maize and soybean (Fig. $3 \mathrm{c}$ and d), were used for model development and calibration, while the limited number of images taken over the MN, IA and IL sites, were employed for model validation (Fig. 3e and f).


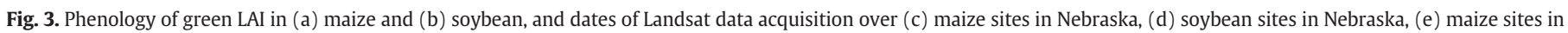
Minnesota, Iowa and Illinois and (f) soybean sites in Minnesota, Iowa and Illinois. 
Four of the Landsat spectral bands with $30 \mathrm{~m}$ spatial resolution were used in this study: blue (band 1: $450-520 \mathrm{~nm}$ ), green (band 2: 520-600 nm), red (band 3: 630-690 nm), and near-infrared (band 4: 750-900 nm). Six chlorophyll-related vegetation indices were tested for GPP estimation (Table 2). These VI were calculated from Landsat surface reflectance data, as well as Landsat TOA reflectance data.

\section{3. $P A R_{\text {in }}$ observations and $P A R_{\text {potential }}$ calculation}

For each study site, hourly PAR $_{\text {in }}$ was measured with point quantum sensors (LI-190, LI-COR Inc., Lincoln, NE) pointing toward the sky and placed $6 \mathrm{~m}$ above the surface. Daytime $\mathrm{PAR}_{\text {in }}$ values were computed by integrating the hourly measurements during a day when $P R_{\text {in }}$ exceeded $1 \mu \mathrm{mol} / \mathrm{m}^{2} / \mathrm{s}$. Daily $\mathrm{PAR}_{\text {in }}$ and $\mathrm{PAR}_{\text {potential }}$ values are presented in $\mathrm{MJ} / \mathrm{m}^{2} / \mathrm{d}$ (Turner et al., 2003).

As we mentioned above (Methodology section), PAR potential can be calculated using various radiative transfer approaches. However, in this paper we calculated $\mathrm{PAR}_{\text {potential }}$ using measured $\mathrm{PAR}_{\text {in }}$ values. Since the daylight duration is mainly determined by the day of a year (DOY) and geographic location, we created profiles of PAR potential as functions of DOY for sites located in Nebraska, Minnesota, Iowa and Illinois, based on daytime $\mathrm{PAR}_{\text {in }}$ obtained during study periods. For each DOY, a maximal $P R_{\text {in }}$ value was found in the 8-day-PAR ${ }_{\text {in }}$ window centered on that particular DOY. This procedure was applied to the entire growing season of a year using the 8-day moving window. The bestfit functions of the relationships between maximal $\mathrm{PAR}_{\text {in }}$ and DOY were found for each year and the variation among the years was very small (coefficient of variation below 3.5\%). Thus, the PAR potential vs. DOY function was defined as the average within the relationship between maximal $\mathrm{PAR}_{\text {in }}$ and DOY for each year. The Landsat images used in our work were mostly acquired when the study sites were under cloud-free conditions. Measured $\mathrm{PAR}_{\text {in }}$ and calculated PAR $\mathrm{P}_{\text {potential }}$ approximations were quite close for the NE sites on the Landsat acquisition dates during the 8-year period from 2001 to 2008, with the difference between $\mathrm{PAR}_{\text {in }}$ and $\mathrm{PAR}_{\text {potential }}$ at $12 \%$ on average and $40 \%$ at most (Fig. 4). For $88 \%$ of all Landsat images, the difference was below $20 \%$. These differences were due to varying atmospheric conditions, including aerosol optical thickness and absorption by water vapor.

\subsection{Canopy reflectance collected at close range}

To assess the quality of atmospheric correction, we used reflectance data collected at close range at the three NE sites. Spectral reflectance measurements at canopy level were made using hyperspectral radiometers mounted on "Goliath", an all-terrain sensor platform (Rundquist et al., 2004). A dual-fiber optic system, with two inter-calibrated Ocean Optics USB2000 radiometers, was used to collect radiometric data in the range of $400-1100 \mathrm{~nm}$ with a spectral resolution of about $1.5 \mathrm{~nm}$. One radiometer equipped with a $25^{\circ}$ field-of-view optical fiber was

Table 2

Vegetation indices retrieved from Landsat data, and used in this study.

\begin{tabular}{lll}
\hline Vegetation index & Formula & Reference \\
\hline Simple ratio (SR) & $\rho_{\text {NIR }} / \rho_{\text {red }}$ & Jordan $(1969)$ \\
Normalized difference & $\left(\rho_{\text {NIR }}-\rho_{\text {red }}\right) /\left(\rho_{\text {NIR }}+\rho_{\text {red }}\right)$ & Rouse et al. \\
$\quad$ vegetation index (NDVI) & & $(1974)$ \\
Enhanced vegetation & $2.5 \times\left(\rho_{\text {NIR }}-\rho_{\text {red }}\right) /\left(1+\rho_{\text {NIR }}\right.$ & Jiang et al. \\
index 2 (EVI2) & $\left.+2.4 \times \rho_{\text {red }}\right)$ & $(2008)$ \\
Green wide dynamic & $\left(\alpha \times \rho_{\text {NIR }}-\rho_{\text {green }}\right) /\left(\alpha \times \rho_{\text {NIR }}\right.$ & This paper \\
range vegetation index & $\left.+\rho_{\text {green }}\right)+(1-\alpha) /(1+\alpha)$, & \\
$\quad$ Green WDRVI) & $\alpha=0.3$ & \\
Green chlorophyll & $\rho_{\text {NIR }} / \rho_{\text {green }}-1$ & Gitelson et al. \\
index (Cl green $)$ & & $(2003,2005)$ \\
\hline
\end{tabular}

a The weight coefficient $\alpha(0<\alpha<1)$ is to attenuate the contribution of $\rho_{\text {NIR }}$ at moderate-to-high green biomass, and to make it comparable to that of $\rho_{\text {red }}$. Based on the dynamic range of the Landsat reflectance used in this analysis, we used $\alpha=0.3$.

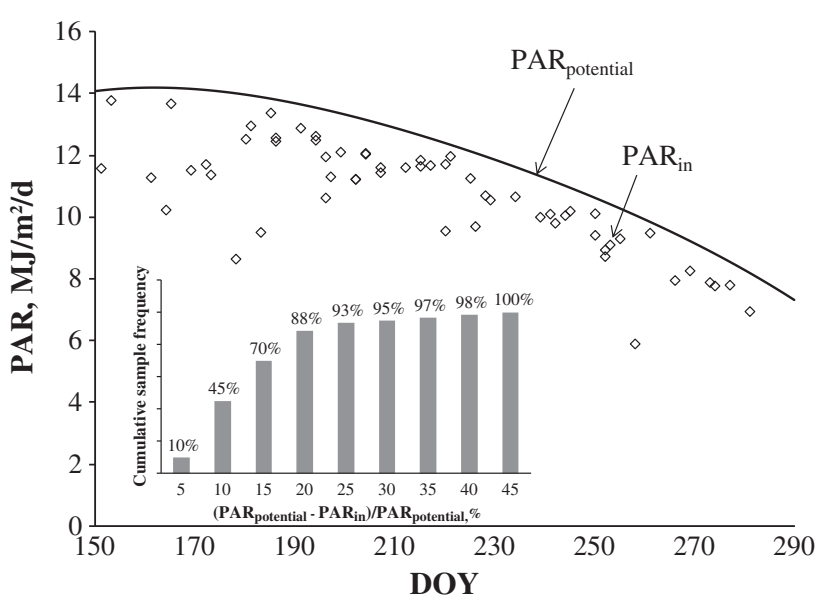

Fig. 4. Temporal behavior of $P A R_{\text {in }}$ measured on the Landsat acquisition dates and calculat-

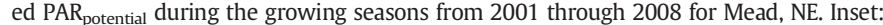
cumulative sample frequency plotted versus difference between $\mathrm{PAR}_{\text {in }}$ and $\mathrm{PAR}_{\text {potential }}$ For $88 \%$ of samples, the difference between $\mathrm{PAR}_{\text {in }}$ and $\mathrm{PAR}_{\text {potential }}$ was below $20 \%$.

pointed downward to measure the upwelling radiance of the crop, and the height of this radiometer was kept constant above the top of the canopy $(6 \mathrm{~m})$ throughout the growing season yielding a sample area with a diameter of $2.4 \mathrm{~m}$. The other radiometer was pointed upward to measure the incident irradiance simultaneously. Radiometric data were collected close to solar noon (between 11:00 and 13:00 local time) when changes in solar zenith angle were minimal. This is 1-2 $\mathrm{h}$ later than the Landsat overpass, however, relative BRDF changes due to this difference are small for both crops (Gitelson and Vina, unpublished). Percent reflectance was then computed based on measured radiance and irradiance (details are given in Gitelson et al., 2006 and Viña et al., 2011). For each site, six randomly selected plots were established with six randomly selected sampling points. Thus, a total of 36 spectra were measured per site at each data acquisition date, and their median value was used as the site reflectance.

Spectral reflectance measurements at close range were carried out from May to October during the growing seasons from 2001 through 2008 , which resulted in a total of 314 reflectance spectra for maize (47 in 2001, 30 in 2002, 92 in 2003, 30 in 2004, 53 in 2005, 13 in 2006, 40 in 2007 and 9 in 2008) and 145 spectra for soybean (54 in 2002, 49 in 2004, 26 in 2006 and 16 in 2008). Since spectral reflectance changed gradually across the growing season, daily canopy reflectance, measured at close range, was interpolated based on measurements taken at cloud-free sampling dates. Such interpolated reflectances, obtained at close range, were simulated in the spectral bands of Landsat for comparison to the Landsat-retrieved surface reflectance on the dates of image acquisition.

\section{Results and discussion}

\subsection{Quality of atmospheric correction}

To assess the quality of Landsat atmospheric correction, reflectances retrieved from spectra collected $6 \mathrm{~m}$ above the top of the canopy were compared with Landsat-retrieved surface reflectance. In blue, green, red and NIR bands, Landsat-retrieved surface reflectance was quite close to reflectance taken at close range for all three sites in Mead, NE from 2001 through 2008, with a maximal CV of $27.7 \%$ and maximal mean normalized bias (MNB) of $18.3 \%$ for the blue band (Fig. 5a) and minimal CV of $16.8 \%$ and minimal MNB of $11.7 \%$ for the NIR band (Fig. 5d). It is worth noting that in all spectral bands, MNB was positive indicating that close range measured reflectance was consistently lower than Landsat surface reflectance. The points 

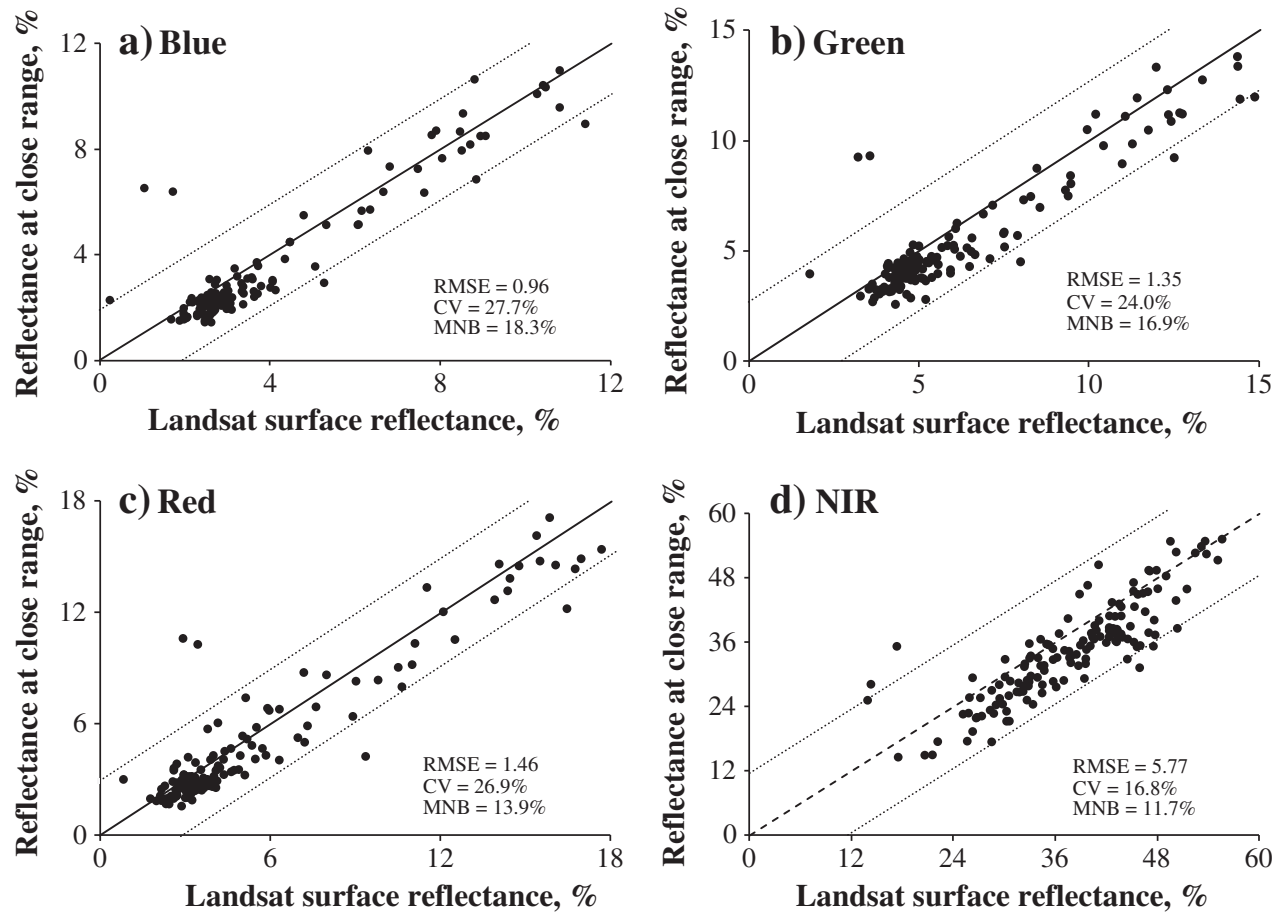

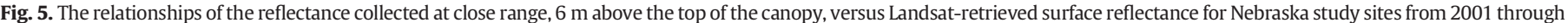

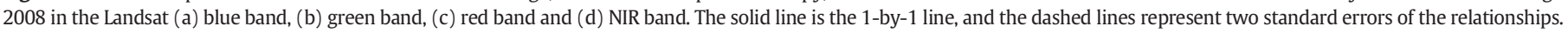

out of the range of the $95 \%$ confidential interval ( 3 of 140 points) were excluded from the database for the model development and calibration.

\subsection{GPP model with $P A R_{\text {potential }}$ vs. model with $P A R_{\text {in }}$}

To assess the accuracy of the models that use $\mathrm{PAR}_{\text {in }}$ (Eq. 3 ) and PAR $_{\text {potential }}$ (Eq. 4), standard errors of GPP estimation by both models, $\mathrm{SE}\left\{\mathrm{PAR}_{\mathrm{in}}\right\}$ and $\mathrm{SE}\left\{\mathrm{PAR}_{\text {potential }}\right\}$, and their difference, $\triangle \mathrm{SE}$, were calculated as:

$\Delta \mathrm{SE}=\left(\mathrm{SE}\left\{\mathrm{PAR}_{\text {in }}\right\}-\mathrm{SE}\left\{\mathrm{PAR}_{\text {potential }}\right\}\right) / \mathrm{SE}\left\{\mathrm{PAR}_{\text {in }}\right\} \times 100 \%$

The value of the difference is positive if the accuracy of the model (Eq. 4) that uses PAR $_{\text {potential }}$ is higher than that of the model (Eq. 3) that uses $\mathrm{PAR}_{\mathrm{in}}$, while the difference is negative if the accuracy of the model (Eq. 4) is lower. For all six VI, as retrieved from Landsat data for both maize and soybean, the accuracy of the

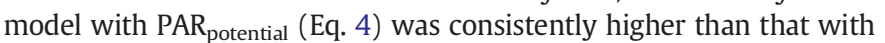
$\mathrm{PAR}_{\text {in }}$ (Eq. 3) - Fig. 6. The model with $\mathrm{PAR}_{\text {potential }}$ was more accurate by at least $5 \%$ for SR to more than $20 \%$ for green NDVI (Fig. 6 ).

One possible reason for such accurate GPP estimation when using $\mathrm{PAR}_{\text {potential }}$ instead of $\mathrm{PAR}_{\mathrm{in}}$ is the well-documented (for maize) saturation of GPP vs. $\mathrm{PAR}_{\text {in }}$ relationship, indicating that a decrease in $\mathrm{PAR}_{\text {in }}$ may not correspond to a decrease in GPP (e.g., Ort, 2001; Suyker et al., 2005). Secondly, under water-limited conditions, photoprotection mechanisms were likely invoked to prevent damage to photosynthetic processes (e.g., Bjo"rkman \& Powles, 1984; Kasahara et al., 2002). So with the same total Chl content, the small decrease of $\mathrm{PAR}_{\text {in }}$ (as on the Landsat acquisition dates) might not be accompanied with a GPP decrease in the same degree. In that case, multiplying by $\mathrm{PAR}_{\mathrm{in}}$, which fluctuated in accordance with small variations in daily weather conditions, may make the values of $\mathrm{VI} \times \mathrm{PAR}_{\text {in }}$ "noisier" than $\mathrm{VI} \times \mathrm{PAR}_{\text {potential }}$ for GPP estimation, as is illustrated in Fig. 7 for green NDVI.

\subsection{Calibration of algorithms}

Concurrent GPP and Landsat observations during 2001-2008 over the three NE sites represented a wide dynamic range of GPP variation
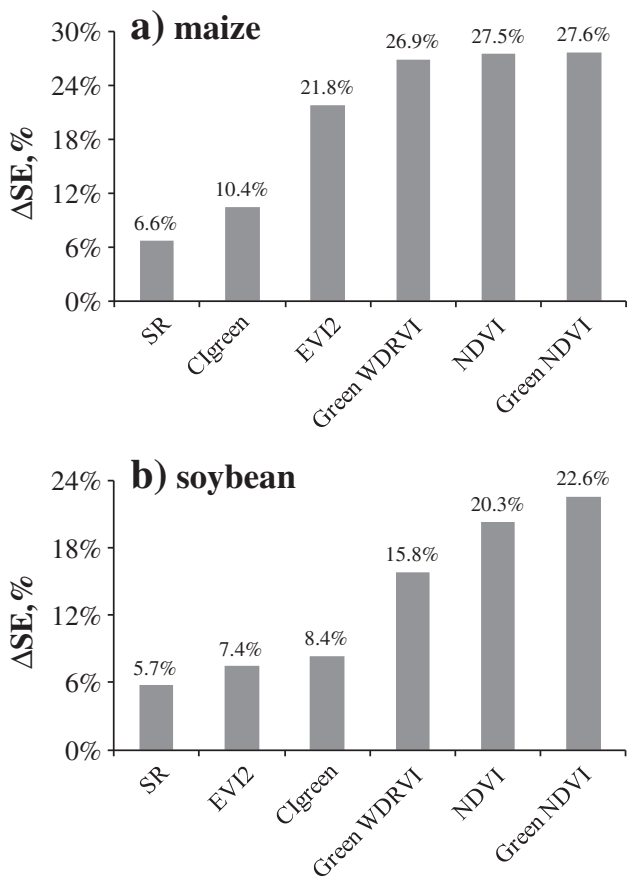

Fig. 6. Difference in standard errors of GPP estimation by two models: Eq. (3) that used $\mathrm{PAR}_{\text {in }}$ and Eq. (4) that used $\mathrm{PAR}_{\text {potential. }} \triangle \mathrm{SE}=\left(\mathrm{SE}\left\{\mathrm{PAR}_{\text {in }}\right\}-\mathrm{SE}\left\{\mathrm{PAR}_{\text {potential }}\right\}\right) / \mathrm{SE}\left\{\mathrm{PAR}_{\text {in }}\right\} \times$ $100 \%$, where $\operatorname{SE}\left\{\mathrm{PAR}_{\mathrm{in}}\right\}$ is the standard error of the model Eq. (3) and $\operatorname{SE}\{\mathrm{PAR}$ potential $\}$ is the standard error of the model Eq. (4). (a) $\triangle \mathrm{SE}$ is for maize data and (b) $\triangle \mathrm{SE}$ is for soybean


that of Eq. (3) with PAR in used for all six VI. 

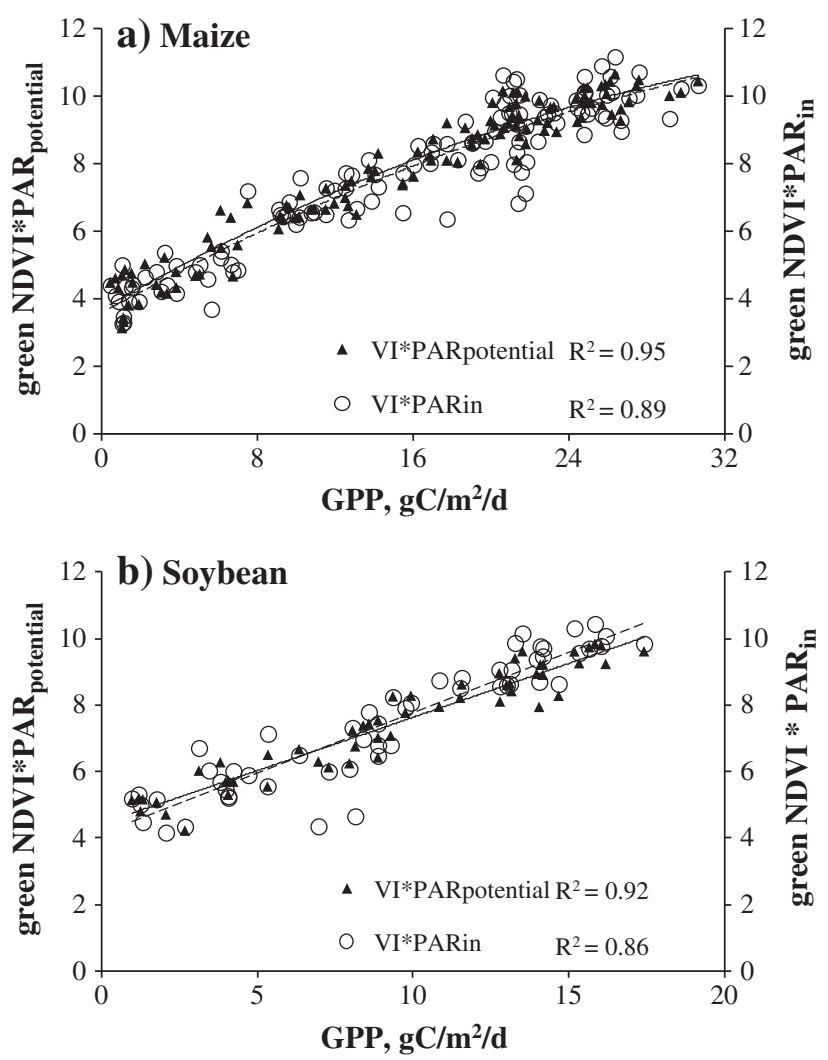

Fig. 7. The relationships of green $\mathrm{NDVI} \times \mathrm{PAR}_{\text {potential }}\left(\mathrm{MJ} / \mathrm{m}^{2} / \mathrm{d}\right)$ vs. GPP and green $\mathrm{NDVI} \times \mathrm{PAR}_{\text {in }}\left(\mathrm{MJ} / \mathrm{m}^{2} / \mathrm{d}\right)$ vs. GPP for (a) maize and (b) soybean. In both maize and soybean, the values of $\mathrm{VI} \times \mathrm{PAR}_{\text {potential }}$ were more closely related to GPP than those of $\mathrm{VI} \times \mathrm{PAR}_{\mathrm{in}}$. The solid line is the best fit function of the relationship green $\mathrm{NDVI} \times \mathrm{PAR}_{\text {potential }} \mathrm{Vs}$. GPP, and the dashed line is the best fit function of the relationship green $\mathrm{NDVI} \times \mathrm{PAR}_{\mathrm{in}} \mathrm{Vs}$. GPP.

(maize GPP ranging from 0 to $31 \mathrm{~g} \mathrm{C} / \mathrm{m}^{2} / \mathrm{d}$; soybean GPP ranging from 0 to $18 \mathrm{~g} \mathrm{C} / \mathrm{m}^{2} / \mathrm{d}$ ). The relationships $\mathrm{VI} \times \mathrm{PAR}_{\text {potential }} \mathrm{VS}$. GPP were established for maize and soybean (Fig. 8). The relationship NDVI $\times$ PARpotential Vs. GPP was nonlinear with slope decreasing as GPP increased (Fig. 8a). The NDVI was a good indicator of low-to-moderate GPP, but it was less accurate in detecting GPP when it exceeded $20 \mathrm{~g} \mathrm{C} / \mathrm{m}^{2} / \mathrm{d}$. At moderate-to-high vegetation densities, (1) red reflectance became almost invariant and, thus, not sensitive to change in Chl content, and (2) NIR reflectance was much higher than the red reflectance, which results in low sensitivity of NDVI to total Chl content above $1 \mathrm{~g} / \mathrm{m}^{2}$ (Gitelson, 2004; Gitelson et al., 2005) as well as to green LAI above $2 \mathrm{~m}^{2} / \mathrm{m}^{2}$ (Viña et al., 2011). Since crop productivity closely relates to total Chl content and green LAI, NDVI lost its sensitivity to moderateto-high GPP values. Note that the relationship NDVI $\times P_{\text {AR }}$ potential Vs. GPP for soybean was much closer to a linear relationship due to a lower maximal Chl content and GPP values in soybean as compared to that for maize.

The relationship green NDVI $\times \mathrm{PAR}_{\text {potential }}$ Vs. GPP was more linear than NDVI $\times \mathrm{PAR}_{\text {potential }} \mathrm{Vs}$. GPP, but still exhibited a decrease in sensitivity to maize GPP exceeding $23-25 \mathrm{~g} \mathrm{C} / \mathrm{m}^{2} / \mathrm{d}$. Green WDRVI $\times \mathrm{PAR}_{\text {potential }}$ and $\mathrm{EVI} 2 \times \mathrm{PAR}_{\text {potential }}$ were linearly related to GPP, thus, they remained sensitive to the wide range of GPP variation. SR and $\mathrm{CI}_{\text {green }}$ were exponentially related to GPP with slopes increasing as GPP increased. These ratio indices were very sensitive to moderate-to-high GPP values, but much less sensitive to low GPP.

While best-fit functions for $\mathrm{VI} \times \mathrm{PAR}_{\text {potential }}$ vs. GPP for VI were nonlinear, except EVI2 and green WDRVI, they may be approximated quite accurately by linear functions. For example, the determination coefficient $\left(R^{2}\right)$ of the nonlinear relationship for $N D V I \times P A R_{\text {potential }}$ in maize was 0.964 , while $R^{2}$ was 0.934 for the linear relationship.
The $\mathrm{R}^{2}$ was 0.916 for $\mathrm{Cl}_{\text {green }} \times \mathrm{PAR}_{\text {potential }}$ in maize with an exponential relationship and 0.905 if using a linear relationship. To compare performances of VI in estimating GPP, the linear relationships for all six $\mathrm{VI} \times \mathrm{PAR}_{\text {potential }}$ were established. Tables $3 \mathrm{a}$ and $3 \mathrm{~b}$ present the linear relationships GPP vs. VI $\times \mathrm{PAR}_{\text {potential, }}$ as well as indicators of uncertainties associated with maize and soybean GPP estimation $\left(R^{2}, S E\right.$ and CV) in NE sites from 2001 through 2008. Overall, all six VI were quite accurate for GPP estimation with CVs below $23 \%$ in maize and below $30 \%$ in soybean. SR was less accurate than other indices for GPP estimation for both maize and soybean, since at moderate-to-high GPP the red reflectance as the denominator of SR is very low (below $3 \%$ and noisy, thus resulting in a pronounced scattering of points away from its best-fit function.

The normalized difference VI (NDVI, green NDVI and green WDRVI) performed better than ratio-based VI (SR, and $\mathrm{CI}_{\text {green }}$ ), especially for soybean data as noted in Table $3 \mathrm{~b}$ (CV was above $25 \%$ for ratio indices while below $19 \%$ for normalized difference VI). To find the reason for the discrepancy, the relationship between GPP/PARpotential and $\mathrm{CI}_{\text {green }}$ for soybean was analyzed. The relationship showed pronounced hysteresis (Fig. 9b): for the same $\mathrm{Cl}_{\text {green }}$, GPP/PAR potential in the green-up stage $(\mathrm{DOY}<220)$ was much higher than in the senescence stage ( $\mathrm{DOY}>220)$. We considered two cases taken during green up (sample A) and senescence (sample B) stages (Fig. 9a). Green LAI was 1.5 for sample $A$ while 0.5 for sample $B$; fraction of absorbed radiation (i.e. fAPAR $_{\text {green }}$ ) in sample A was three times higher than in sample B. In contrast, the total LAI in the senescence stage (sample B) was higher than in sample A: 2.3 vs. 1.5 due to a higher total amount of both photosynthetic and non-photosynthetic leaves in sample B, which caused higher light scattering and higher $\rho_{\text {NIR }}$ (Fig. 9c). Such hysteresis of $\rho_{\text {NIR }}$ resulted in the hysteresis of ratio VI for which NIR reflectance acted as a numerator (example for $\mathrm{Cl}_{\text {green }}$ in Fig. 9b). For soybean, accuracy of GPP estimation by EVI2 decreased significantly comparably to maize (Table 3); it is due to NIR reflectance plays the main role in EVI2 formulation. For NDVI, green NDVI, and green WDRVI, the effect of NIR reflectance hysteresis was attenuated by normalization; thus they performed much better for soybean GPP estimation than ratio VI with CVs below 17.4\%. This effect was less pronounced in maize due to a significant decrease in leaf inclination, and thus a decrease in NIR reflectance during senescence.

All six VI used in the current study were species specific for maize and soybean. For the same GPP, the value of $\mathrm{VI} \times \mathrm{PAR}_{\text {potential }}$ in soybean was consistently higher than that in maize with VI calculated from reflectance in NIR and either green or red bands. This result is due to contrasting leaf structures and canopy architectures of maize and soybean (Gitelson, 2011; Peng \& Gitelson, 2011b). Thus, prior information about crop types is required when using Landsat data for GPP estimation. However, in the case of green NDVI, the relationships for maize and soybean were close, allowing accurate GPP estimation in both crops using the same algorithm with no re-parameterization (Fig. 10).

\subsection{Validation of algorithms}

The images and GPP values were obtained during an eight-year period over three irrigated and rainfed fields in Nebraska with different field histories, crop management and weather conditions. However, the algorithms established based on data from different fields during 8 years of observation were accurate in estimating GPP (Tables 3a and $3 \mathrm{~b}$, Fig. 8). In order to explore the possibility of using a unified algorithm for GPP estimation across the US, one needs to examine whether the algorithm, established in NE, works for study sites located in different geographic regions with no re-parameterization of their coefficients, and assess the associated uncertainties of GPP estimation. Fig. 11 presents the relationships between GPP measured in the MN, IA and IL sites and the product $\mathrm{VI} \times \mathrm{PAR}_{\text {potential }}$ for $\mathrm{VI}$ that were found to be the best in the NE sites (Tables 3a and 3b, green WDRVI for 

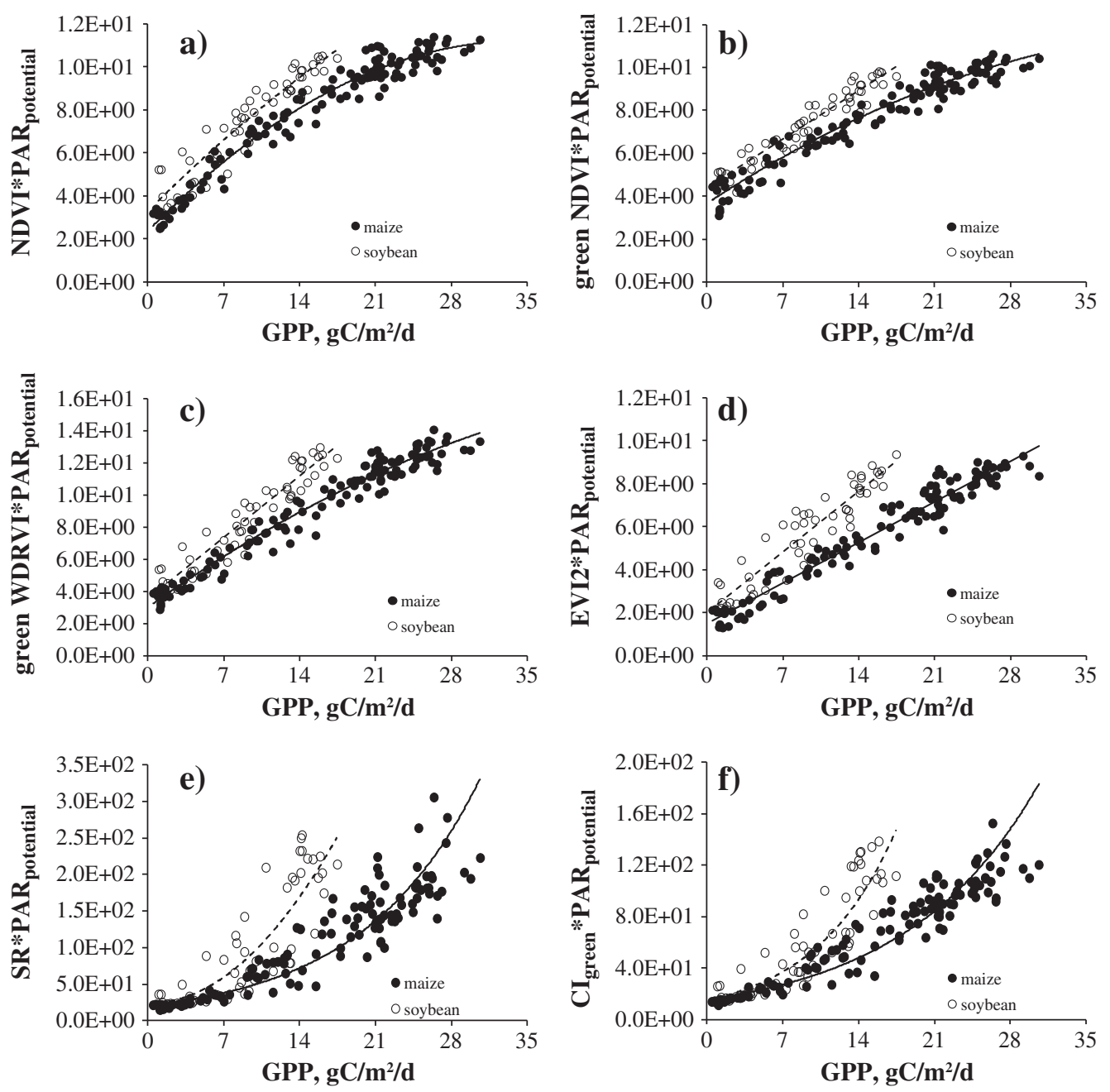

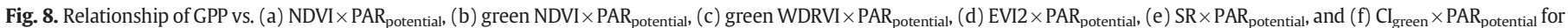
maize and soybean established in the Nebraska sites from 2001 through 2008.

maize, and green NDVI for soybean). These VI were calculated using surface reflectances retrieved from Landsat images taken over the MN, IA and IL sites. Best-fit linear functions, established in the NE sites (Tables 3a and 3b), with two standard errors of GPP estimation, are also included. Despite the differences in climatic conditions and geographic locations among study sites from four states, more than $84 \%$ of the maize samples and $62 \%$ of the soybean samples fell within the $95 \%$ confidential interval of the algorithms calibrated at the NE sites. This result shows potential for estimating GPP across the nation or even across the globe using satellite data and a unified algorithm based on the model (Eq. 4).

However, there was consistent overestimation of GPP in MN, IA and IL when using the algorithm established in NE (MNB was 30.1\%

Table 3a

The algorithms for daytime GPP estimating in irrigated and rainfed maize sites at Mead, Nebraska during 2001-2008 (120 samples), with determination coefficients $\left(R^{2}\right)$, standard errors (SE) and coefficients of variation (CV) presented. GPP ranged from 0 to $30 \mathrm{~g} \mathrm{C} / \mathrm{m}^{2} / \mathrm{d}$.

\begin{tabular}{lllll}
\hline VI & $\mathrm{GPP}=\mathrm{ax}+\mathrm{b}\left(\mathrm{x}=\mathrm{VI} \times \mathrm{PAR}_{\text {potential }}\right)$ & $\mathrm{R}^{2}$ & $\mathrm{SE}, \mathrm{g} \mathrm{C} / \mathrm{m}^{2} / \mathrm{d}$ & $\mathrm{CV}, \%$ \\
\hline Green WDRVI & $\mathrm{GPP}=2.63 \mathrm{x}-8.59$ & 0.95 & 1.90 & 12.1 \\
EVI2 & $\mathrm{GPP}=3.54 \mathrm{x}-4.62$ & 0.95 & 1.92 & 12.3 \\
Green NDVI & $\mathrm{GPP}=4.00 \mathrm{x}-15.4$ & 0.94 & 2.20 & 14.0 \\
NDVI & $\mathrm{GPP}=3.11 \mathrm{x}-9.22$ & 0.93 & 2.22 & 14.2 \\
$\mathrm{Cl}_{\text {green }}$ & $\mathrm{GPP}=3.57 \mathrm{x}+9.29$ & 0.91 & 2.67 & 17.0 \\
SR & $\mathrm{GPP}=0.114 \mathrm{x}+3.02$ & 0.84 & 3.49 & 22.2 \\
\hline
\end{tabular}

for maize and $52.1 \%$ for soybean). One possible explanation for the error was the different planting densities in the MN, IL and IA sites: it was approximately $15 \%$ higher than in the NE sites (for maize: $86,000 \mathrm{pl} / \mathrm{ha}$ in $\mathrm{MN}$, IL and IA vs. $75,000 \mathrm{pl} / \mathrm{ha}$ in NE; for soybean: $340,000 \mathrm{pl} / \mathrm{ha}$ in $\mathrm{MN}$, IL and IA and around $300,000 \mathrm{pl} / \mathrm{ha}$ in NE). Plant density affects vertical light profile and, thus, the light climate

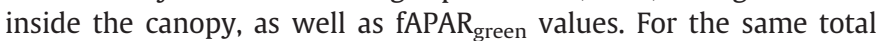
Chl content and amount of incoming radiation, more light may be absorbed and used for photosynthesis by the sparsely distributed plants due to more open areas available and less shadows of nearby plants (Peng \& Gitelson, 2011a). Thus, at the same value of VI $\times$ PARpotential, the site with lower planting density, as in NE, produces more GPP than sites with higher planting densities, e.g., MN, IA and IL. In

Table 3b

The algorithms for daytime GPP estimating in irrigated and rainfed soybean sites at Mead, Nebraska in 2002, 2004, 2006 and 2008 (54 samples), with determination coefficients $\left(\mathrm{R}^{2}\right)$, standard errors (SE) and coefficients of variation (CV) presented. GPP ranged from 0 to $19 \mathrm{~g} \mathrm{C} / \mathrm{m}^{2} / \mathrm{d}$.

\begin{tabular}{lllll}
\hline VI & $\mathrm{GPP}=\mathrm{ax}+\mathrm{b}\left(\mathrm{x}=\mathrm{VI} \times \mathrm{PAR}_{\text {potential }}\right)$ & $\mathrm{R}^{2}$ & $\mathrm{SE}, \mathrm{g} \mathrm{C} / \mathrm{m}^{2} / \mathrm{d}$ & $\mathrm{CV}, \%$ \\
\hline Green NDVI & $\mathrm{GPP}=2.86 \mathrm{x}-11.9$ & 0.92 & 1.40 & 14.9 \\
Green WDRVI & $\mathrm{GPP}=1.66 \mathrm{x}-4.98$ & 0.90 & 1.54 & 16.3 \\
NDVI & $\mathrm{GPP}=2.07 \mathrm{x}-6.19$ & 0.89 & 1.65 & 17.4 \\
$\mathrm{EVI} 2$ & $\mathrm{GPP}=2.15 \mathrm{x}-3.06$ & 0.87 & 1.79 & 18.9 \\
$\mathrm{CI}_{\text {green }}$ & $\mathrm{GPP}=0.106 \mathrm{x}+2.63$ & 0.76 & 2.42 & 25.6 \\
$\mathrm{SR}$ & $\mathrm{GPP}=0.0515 \mathrm{x}+3.91$ & 0.67 & 2.79 & 29.5 \\
\hline
\end{tabular}


a)

\begin{tabular}{lll}
\hline Sample \# & A & B \\
\hline Date & $7 / 15 / 2008$ & $9 / 17 / 2008$ \\
fAPAR $_{\text {green }}{\text { Green LAI, }{ }^{2} / \mathrm{m}^{2}}^{2}$ & 0.78 & 0.19 \\
Total LAI, $\mathrm{m}^{2} / \mathrm{m}^{2}$ & 1.5 & 0.5 \\
NIR, \% & 33 & 2.3 \\
\hline
\end{tabular}
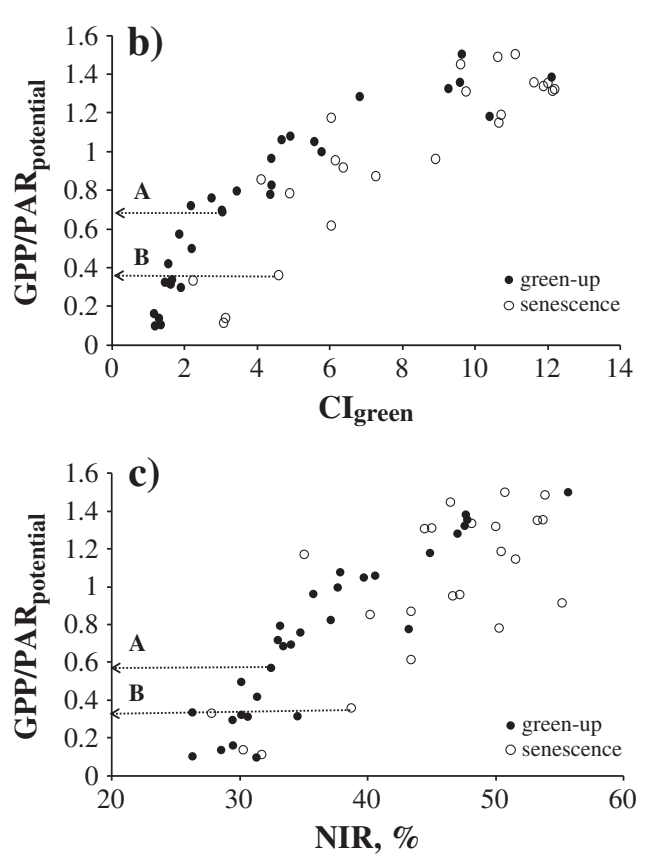

Fig. 9. (a) Soybean biophysical characteristics for two cases: sample $A$ at the green-up stage and sample B at the senescence stage. The relationship of GPP/PAR potential vs. (b) $\mathrm{Cl}_{\text {green }}$ and (c) NIR reflectance.

addition, the solar radiation availability for the growing season differed among sites in NE, MN, IA and IL. For the same crop total Chl content in different geographic locations, PAR $_{\text {potential }}$ varies as site latitude changes; however, it is not clear how locational difference affects GPP and whether algorithms calibrated in one geographic region could be used for very different latitudes with no re-parameterization. Further studies are required to identify sources of uncertainties when the unified algorithms are applied to different geographic locations and crop management systems.

The model (Eq. 4), which relies on the product of crop total Chl and PAR potential, can be accurately applied to estimate GPP in maize and soybean based entirely on Landsat data. However, the procedures

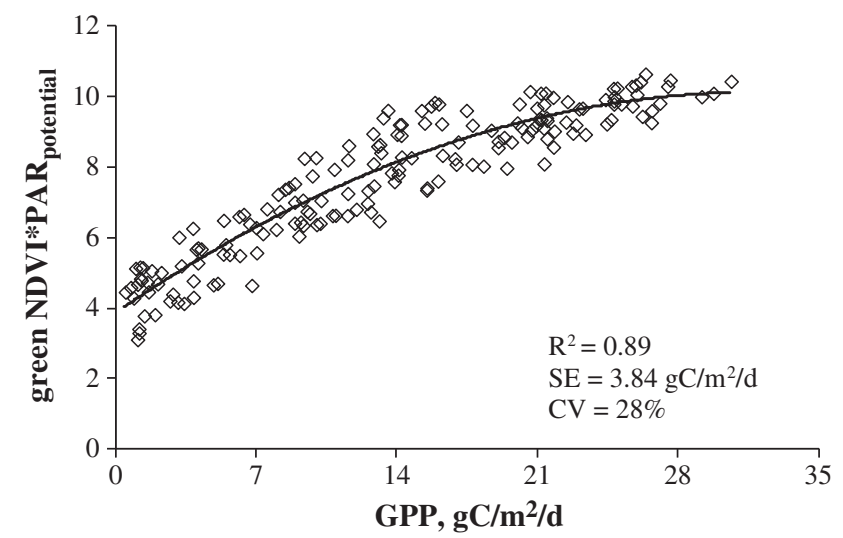

Fig. 10. Relationship of green NDVI $\times \mathrm{PAR}_{\text {potential }}$ Vs. GPP for maize and soybean data combined, established in the Nebraska sites from 2001 through 2008.
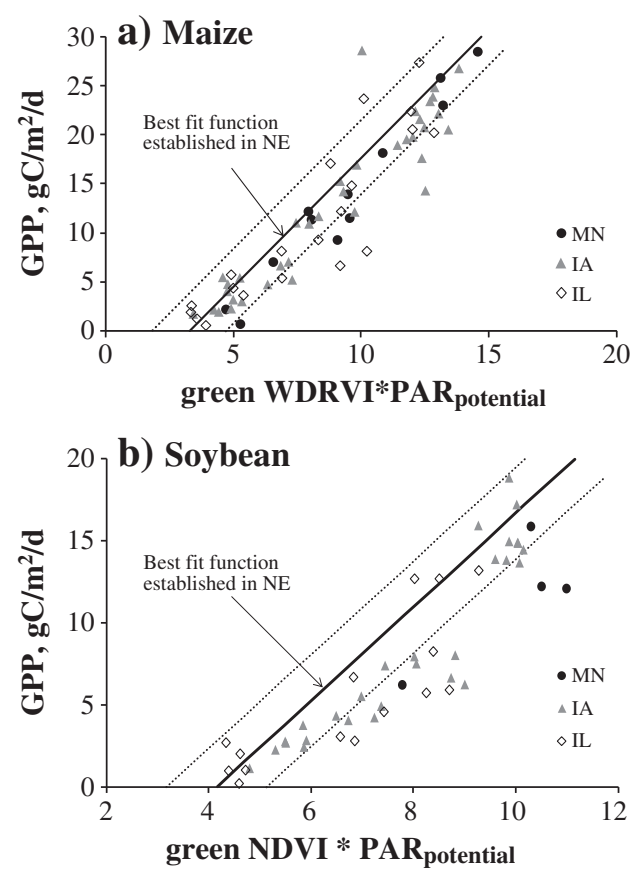

Fig. 11. Relationships between GPP, measured in the Minnesota, Iowa and Illinois sites, and the product $\mathrm{VI} \times \mathrm{PAR}_{\text {potential }}$ for $\mathrm{VI}$ that were found to be the best in the Nebraska sites for (a) maize and (b) soybean. The solid lines represent best-fit linear functions established in the Nebraska sites (Tables $3 \mathrm{a}$ and $3 \mathrm{~b}$ ). The dotted lines represent two standard errors of the relationships.

of calibration and validation of the model are far from perfect and contain several uncertainties. One of them is due to the incongruity of time scales between Landsat observations and GPP data used in the model. The Landsat image was obtained around 10 am for each orbital passage, while GPP was calculated on a daylong basis. During a day, although crop Chl content remains the same, instantaneous GPP may change significantly due to changes in incoming radiation. Another uncertainty of the model (Eq. 4) arises because of its failure to detect the variation in GPP related to short-term (minutes to hours) changes in controlling factors, such as high temperatures and/or a decrease in soil moisture, which do not immediately affect crop Chl content.

\subsection{GPP estimation using raw Landsat data}

Since Landsat data are now freely available, it is convenient to use Landsat at-sensor radiance data. However, atmospheric correction is required to convert Landsat at-sensor radiances to surface reflectance. The procedure of atmospheric correction is quite complicated and challenging, which may be impractical for users with little or no appropriate software experience. So, we decided to address the following question: how accurately does the model (Eq. 4) work for estimating crop GPP with Landsat top-of-atmosphere radiance retrieved from images without atmospheric correction? Tables 4a and $4 \mathrm{~b}$ provide measures of accuracy for the model (Eq. 4), $\mathrm{R}^{2}$, SE and $\mathrm{CV}$, for GPP estimation using VI retrieved from Landsat atmospherically corrected images, as well as raw, uncorrected images for maize and soybean at the NE sites from 2001 through 2008. All six indices, calculated using TOA reflectance, were able to estimate GPP reasonably well, with CVs below 20\% in maize and CVs below $30 \%$ in soybean. One reason for such an accurate GPP estimation using the Landsat TOA reflectance is that Landsat images, used in this study, were mostly taken on clear days, when reflectances were not strongly affected by atmospheric gasses and aerosols. In addition, VI were calculated as mathematical combinations of reflectance ratios or as 
Table 4a

n-

Determination coefficients $\left(\mathrm{R}^{2}\right)$, standard errors (SE) and coefficients of variation $(\mathrm{CV})_{\mathrm{O}}$ for the relationship GPP vs. VI $\times P_{\text {PAR }}$ potential with VI retrieved from Landsat atmospher- ${ }_{\text {- }}$ ically corrected and raw (uncorrected) images taken over maize sites in Nebraska from ${ }^{\mathrm{r}}$ 2001 through 2008.

\begin{tabular}{|c|c|c|c|c|c|c|}
\hline \multirow{2}{*}{$\begin{array}{l}\text { Vegetation } \\
\text { index }\end{array}$} & \multicolumn{3}{|c|}{ Surface reflectance } & \multicolumn{3}{|c|}{ TOA reflectance } \\
\hline & $\mathrm{R}^{2}$ & $\mathrm{SE}, \mathrm{g} \mathrm{C} / \mathrm{m}^{2} / \mathrm{d}$ & $\mathrm{CV}, \%$ & $\mathrm{R}^{2}$ & SE, $\mathrm{g} \mathrm{C} / \mathrm{m}^{2} / \mathrm{d}$ & $\mathrm{CV}, \%$ \\
\hline Green WDRVI & 0.95 & 1.90 & 12.1 & 0.93 & 2.23 & 14.2 \\
\hline EVI2 & 0.95 & 1.92 & 12.3 & 0.95 & 2.03 & 13.0 \\
\hline Green NDVI & 0.94 & 2.20 & 14.0 & 0.93 & 2.36 & 15.0 \\
\hline NDVI & 0.93 & 2.22 & 14.2 & 0.93 & 2.24 & 14.3 \\
\hline $\mathrm{CI}_{\text {green }}$ & 0.91 & 2.67 & 17.0 & 0.81 & 2.62 & 16.7 \\
\hline SR & 0.84 & 3.49 & 22.2 & 0.88 & 2.95 & 18.8 \\
\hline
\end{tabular}

\section{Table 4b}

Determination coefficients $\left(\mathrm{R}^{2}\right)$, standard errors (SE) and coefficients of variation (CV) for the relationship GPP vs. VI $\times$ PAR $_{\text {potential }}$ with VI retrieved from Landsat atmospherically corrected and raw (uncorrected) images taken over soybean sites in Nebraska in 2002, 2004, 2006 and 2008.

\begin{tabular}{llllllll}
\hline \multirow{2}{*}{$\begin{array}{l}\text { Vegetation } \\
\text { index }\end{array}$} & \multicolumn{3}{l}{ Surface reflectance } & & \multicolumn{3}{l}{ TOA reflectance } \\
\cline { 2 - 3 } & $\mathrm{R}^{2}$ & $\mathrm{SE}, \mathrm{g} \mathrm{C} / \mathrm{m}^{2} / \mathrm{d}$ & $\mathrm{CV}, \%$ & & $\mathrm{R}^{2}$ & $\mathrm{SE}, \mathrm{g} \mathrm{C} / \mathrm{m}^{2} / \mathrm{d}$ & $\mathrm{CV}, \%$ \\
\hline Green NDVI & 0.92 & 1.40 & 14.9 & & 0.78 & 2.21 & 23.5 \\
Green WDRVI & 0.90 & 1.54 & 16.3 & & 0.77 & 2.33 & 24.7 \\
NDVI & 0.89 & 1.65 & 17.4 & & 0.84 & 1.96 & 20.7 \\
EVI2 & 0.87 & 1.79 & 18.9 & & 0.77 & 2.33 & 24.7 \\
$\mathrm{Cl}_{\text {green }}$ & 0.76 & 2.42 & 25.6 & & 0.70 & 2.69 & 28.5 \\
SR & 0.67 & 2.79 & 29.5 & & 0.69 & 2.74 & 29.0 \\
\hline
\end{tabular}

malized differences to reduce the dependence on atmospheric effects. Further analyses are needed to confirm these findings.

\section{Conclusions}

The model based on total crop chlorophyll content and potential PAR was tested for estimating GPP in maize and soybean, crops with contrasting leaf structures and canopy architectures. Several vegetation indices were used as proxies of chlorophyll content. The model was capable of estimating GPP using atmospherically corrected Landsat data with coefficients of variation of $23 \%$ for maize and below $30 \%$ for soybean. The indices using green and NIR Landsat bands were found to be the most accurate in GPP estimation. Our results showed that the model based solely on satellite data is robust in estimating GPP and represents a significant improvement over MODIS GPP for croplands. One drawback is the poor temporal resolution of Landsat compared to MODIS. A data fusion of MODIS and Landsat may be a worthwhile next step in the effort to estimate daily GPP. The model was also capable of estimating GPP using raw imagery; i.e., TOA reflectance. The algorithms established in the NE maize and soybean study sites were validated for the same crops in Minnesota, Iowa and Illinois. Future study should determine uncertainties of established algorithms for GPP estimation in other crops with no re-parameterization. It is also essential to test these algorithms in different geographic regions.

In this paper, we used maximal values of measured $\mathrm{PAR}_{\text {in }}$ as a surrogate for $\mathrm{PAR}_{\text {potential. }}$ The next step is to calculate $\mathrm{PAR}_{\text {potential }}$ using radiative transfer approaches and to test the model using Landsat and MODIS data with calculated daily PAR $_{\text {potential. }}$ Having 11 years GPP data at three Nebraska AmeriFlux sites will allow comprehensive testing of the model based on chlorophyll related indices and calculated $\mathrm{PAR}_{\text {potential. }}$

\section{Acknowledgments}

This research was supported by NASA NACP grant no. NNX08AI75G and partially by the U.S. Department of Energy: (a) EPSCoR program, grant no. DE-FG-02-00ER45827 and (b) Office of Science (BER), grant no. DE-FG03-00ER62996. We sincerely appreciate the support and the use of facilities and equipment provided by the Center for Advanced
Land Management Information Technologies (CALMIT) and Carbon Sequestration Program, University of Nebraska-Lincoln.

\section{References}

Almond, S., Boyd, D. S., Dash, J., Curran, P. J., Hill, R. A., \& Foody, G. M. (2010). Estimating terrestrial gross primary productivity with the Envisat Medium Resolution Imaging Spectrometer (MERIS) Terrestrial Chlorophyll Index (MTCI). Geoscience and Remote Sensing Symposium (IGARSS) 2010 IEEE International (pp. 4792-4795). Honolulu, HI.

Baker, J., \& Griffis, T. (2005). Examining strategies to improve the carbon balance of corn/soybean agriculture using eddy covariance and mass balance techniques. Agricultural and Forest Meteorology, 128, 163-177.

Baret, F., Houles, V., \& Guerif, M. (2007). Quantification of plant stress using remote sensing observations and crop models: The case of nitrogen management. Journal of Experimental Botany, 58(4), 869-880, doi:10.1093/jxb/erl231.

Bjo"rkman, O., \& Powles, S. B. (1984). Inhibition of photosynthetic reactions under water stress: Interaction with light level. Planta, 161, 490-504.

Cassman, K. G., \& Wood, S. (2005). Cultivated systems. Millennium ecosystem assessment: Global ecosystem assessment report on conditions and trends (pp. 741-789). Washington D.C.: Island Press.

Ciganda, V., Gitelson, A. A., \& Schepers, J. (2008). Vertical profile and temporal variation of chlorophyll in maize canopy: Quantitative "crop vigor" indicator by means of reflectance-based techniques. Agronomy Journal, 100, 1409-1417, doi:10.2134/agronj2007.0322.

Dash, J., \& Curran, P. J. (2004). The MERIS terrestrial chlorophyll index. International Journal of Remote Sensing, 25, 5003-5013.

Feng, M., Huang, C., Channan, S., Vermote, E., Masek, J., \& Townshend, J. R. (2011). Quality assessment of Landsat surface reflectance products using MODIS data. Computers $\mathcal{E}$ Geosciences, 38, 9-22.

Gitelson, A. A. (2004). Wide dynamic range vegetation index for remote quantification of biophysical characteristics of vegetation. Journal of Plant Physiology, 161(2), 165-173.

Gitelson, A. A. (2011). Non-destructive estimation of foliar pigment (chlorophylls, carotenoids and anthocyanins) contents: Espousing a semi-analytical three-band model. In P. S. Thenkabail, J. G. Lyon, \& Huete (Eds.), Hyperspectral remote sensing of vegetation (pp. 141-165). : Taylor and Francis.

Gitelson, A. A., Verma, S. B., Viña, A., Rundquist, D. C., Keydan, G., Leavitt, B., et al. (2003). Novel technique for remote estimation of $\mathrm{CO}_{2}$ flux in maize. Geophysical Research Letters, 30(9), 1486, doi:10.1029/2002GL016543.

Gitelson, A. A., Viña, A., Ciganda, V., Rundquist, D. C., \& Arkebauer, T. J. (2005). Remote estimation of canopy chlorophyll content in crops. Geophysical Research Letters, 32, L08403, doi:10.1029/2005GL022688.

Gitelson, A. A., Viña, A., Masek, J. G., Verma, S. B., \& Suyker, A. E. (2008). Synoptic monitoring of gross primary productivity of maize using Landsat data. IEEE Geoscience and Remote Sensing Letters, 5, 2, doi:10.1109/LGRS.2008.915598.

Gitelson, A. A., Viña, A., Verma, S. B., Rundquist, D. C., Arkebauer, T. J., Keydan, G., et al. (2006). Relationship between gross primary production and chlorophyll content in crops: Implications for the synoptic monitoring of vegetation productivity. Geophysical Research Letters, 111, D08S11, doi:10.1029/2005JD006017.

Gitelson, A. A., Wardlow, B. D., Keydan, G. P., \& Leavitt, B. (2007). An evaluation of MODIS 250-m data for green LAI estimation in crops. Geophysical Research Letters, 34, L20403, doi:10.1029/2007GL031620.

Hall, F. G., Huemmrich, K. F., Goetz, S. J., Sellers, P. J., \& Nickeson, J. E. (1992). Satellite remote sensing of surface energy balance: Success, failures and unresolved issues in FIFE. Journal of Geophysical Research, 97, 19061-19089.

Harris, A., \& Dash, J. (2010). The potential of the MERIS terrestrial chlorophyll index for carbon flux estimation. Remote Sensing of Environment, 114, 1856-1862.

Hatfield, J. L., Jaynes, D. B., Burkart, M. R., Cambardella, C. A., Moorman, T. B., Prueger, J. H., et al. (1999). Water quality in Walnut Creek Watershed: Setting and farming practices. Journal of Environmental Quality, 28, 11-24.

Heinsch, F. A., Zhao, M., Running, S. W., Kimball, J. S., Nemani, R. R., Davis, K. J., et al. (2006). Evaluation of remote sensing based terrestrial productivity from MODIS using regional tower eddy flux network observations. IEEE Transactions on Geoscience and Remote Sensing, 44, 1908-1925, doi:10.1109/TGRS.2005.85396.

Hollinger, S. E., Bernacchi, C. J., \& Meyers, T. P. (2005). Carbon budget of mature no-till ecosystem in North Central Region of the United States. Agricultural and Forest Meteorology, 130, 59-69.

Houborg, R., Anderson, M. C., Daughtry, C. S. T., Kustas, W. P., \& Rodell, M. (2011). Using leaf chlorophyll to parameterize light-use-efficiency within a thermal-based carbon, water and energy exchange model. Remote Sensing of Environment, 115(7), 1694-1705.

Jiang, Z., Huete, A. R., Didan, K., \& Miura, T. (2008). Development of a two-band enhanced vegetation index without a blue band. Remote Sensing of Environment, 112, 3833-3845.

Jones, H. G., \& Vaughan, R. A. (2011). Remote sensing of vegetation. New York: Oxford University press 353.

Jordan, C. F. (1969). Derivation of leaf area index from quality of light in the forest floor. Ecology, 50, 663-666.

Kasahara, M., Kagawa, T., Oikawa, K., Suetsugu, N., Miyao, M., \& Wada, M. (2002). Chloroplast avoidance movement reduces photodamage in plants. Nature, 420, 829-832.

Kaufman, Y. J., Wald, A. E., Remer, L. A., Gao, B. -C., Li, R. -R., \& Flynn, L. (1997). The MODIS 2.1-um channel-Correlation with visible reflectance for use in remote 
sensing of aerosol. IEEE Transactions on Geoscience and Remote Sensing, 35(5), 1286-1296.

Kotchenova, S. Y., \& Vermote, E. (2007). Validation of a vector version of the 6 S radiative transfer code for atmospheric correction of satellite data. Part II: Homogeneous Lambertian and anisotropic surfaces. Applied Optics, 46(20), 4455-4464.

Lee, D. S., Storey, J. C., Choate, M. J., \& Hayes, R. (2004). Four years of Landsat-7 on-orbit geometric calibration and performance. IEEE Transactions on Geoscience and Remote Sensing, 42, 2786-2795.

Lieth, H., \& Whittaker, R. H. (1975). Primary productivity of the biosphere. Ecological studies, 14. (pp. 7-16) : Springer-Verlag.

Lyapustin, A. (2003). Interpolation and profile correction (IPC) method for shortwave radiative transfer in spectral intervals of gaseous absorption. Journal of Atmospheric Science, 60, 865-871.

Malmstrom, C. M., Thompson, M. V., Juday, G. P., Los, S. O., Randerson, J. T., \& Field, C. B. (1997). Interannual variation in global-scale net primary production: Testing model estimates. Global Biogeochemical Cycles, 11, 367-392.

Masek, J. G., Vermote, E. F., Saleous, N., Wolfe, R., Hall, F. G., Huemmrich, F., et al. (2006). A Landsat surface reflectance data set for North America. 990-2000. Geoscience and Remote Sensing Letters, 3, 68-72.

Monteith, J. L. (1972). Solar radiation and productivity in tropical ecosystems. Journal of Applied Ecology, 9, 744-766.

Monteith, J. L. (1977). Climate and the efficiency of crop production in Britain. Philosophical Transactions of the Royal Society of London, 281, 277-294.

Myneni, R. B., Nemani, R. R., \& Running, S. W. (1997). Estimation of global leaf area index and absorbed PAR using radiative transfer models. IEEE Transactions on Geoscience and Remote Sensing, 35, 1380-1393.

Ort, D. R. (2001). When there is too much light. Plant Physiology, 125(1), 29-32.

Peng, Y., \& Gitelson, A. A. (2011a). Application of chlorophyll-related vegetation indices for remote estimation of maize productivity. Agricultural and Forest Meteorology, $151,1267-1276$.

Peng, Y., \& Gitelson, A. A. (2011b). Remote estimation of gross primary productivity in soybean and maize based on total crop chlorophyll content. Remote Sensing of Environment, 117, 440-448.

Peng, Y., Gitelson, A. A., Keydan, G., Rundquist, D. C., \& Moses, W. (2011). Remote estimation of gross primary production in maize and support for a new paradigm based on total crop chlorophyll content. Remote Sensing of Environment, 115, 978-989.

Reeves, M. C., Zhao, M., \& Running, S. W. (2004). Usefulness and limits of MODIS GPP for estimating wheat yield. International Journal of Remote Sensing, 26(7), 1403-1421.

Rouse, J. W., Haas, R. H., Jr., Schell, J. A., \& Deering, D. W. (1974). Monitoring vegetation systems in the Great Plains with ERTS. NASA SP-351. Third ERTS-1 Symposium NASA, 1. (pp. 309-317) Washington, DC.

Rundquist, D. C., Perk, R., Leavitt, B., Keydan, G. P., \& Gitelson, A. A. (2004). Collecting spectral data over cropland vegetation using machine-positioning versus handpositioning of the sensor. Computers and Electronics in Agriculture, 43, 173-178.

Running, S. W., Nemani, R. R., Heinsch, F. A., Zhao, M. S., Reeves, M., \& Hashimoto, H. (2004). A continuous satellite-derived measure of global terrestrial primary production. Bioscience, 54, 547-560.

Running, S. W., Thornton, P. E., Nemani, R., \& Glassy, J. M. (2000). Global terrestrial gross and net primary productivity from the earth observing system. In O. E. Sala, R. B. Jackson, H. A. Mooney, \& R. W. Howarth (Eds.), Methods in ecosystem science (pp. 44-57). New York: Springer-Verlag.

Sakamoto, T., Gitelson, A. A., Wardlow, B. D., Verma, S. B., \& Suyker, A. E. (2011) Estimating daily gross primary production of maize based only on MODIS WDRVI and shortwave radiation data. Remote Sensing of Environment, 115(12), 3091-3101.
Sims, D. A., Rahman, A. F., Cordova, V. D., El-Masri, B. Z., Baldocchi, D. D., Flanagan, L. B et al. (2006). On the use of MODIS EVI to assess gross primary productivity of North American ecosystems. Journal of Geophysical Research, 111, G04015, doi: 10.1029/2006JG000162.

Suyker, A. E., Verma, S. B., Burba, G. G., \& Arkebauer, T. J. (2005). Gross primary production and ecosystem respiration of irrigated maize and irrigated soybean during a growing season. Agricultural and Forest Meteorology, 131, 180-190.

Terry, N. (1980). Limiting factors in photosynthesis. I. Use of iron stress to control photochemical capacity in vivo. Plant Physiology, 65, 114-120.

Turner, D. P., Ritts, W. D., Cohen, W. B., Maeirsperger, T. K., Gower, S. T., Kirschbaum, A. A., et al. (2005). Site-level evaluation of satellite-based global terrestrial GPP and NPP monitoring. Global Change Biology, 11, 666-684.

Turner, D., Ritts, W., Zhao, M., Kurc, S. A., Dunn, A., Wofsy, S., et al. (2006). Assessing interannual variation in MODIS-based estimates of gross primary production. IEEE Transactions on Geoscience and Remote Sensing, 44(7), 1899-1907.

Turner, D. P., Urbanski, S., Bremer, D., Wofsy, S., Meyers, T., Gower, S. T., et al. (2003). A cross-biome comparison of daily light use efficiency for gross primary production. Global Change Biology, 9, 383-395.

Verma, S. B., Dobermann, A., Cassman, K. G., Walters, D. T., Knops, J. M., Arkebauer, T. J., et al. (2005). Annual carbon dioxide exchange in irrigated and rainfed maize-based agroecosystems. Agricultural and Forest Meteorology, 131, 77-96.

Vermote, E. F., Saleous, N. El, Justice, C. O., Kaufman, Y. J., Privette, J. L., Remer, L., et al. (1997a). Atmospheric correction of visible to middle-infrared EOS-MODIS data over land surfaces: Background, operational algorithm, and validation. Journal of Geophysical Research, 102, 17131-17141.

Vermote, E. F., Tanré, D., Deuzé, J. L., Herman, M., \& Morcrette, J. J. (1997b). Second simulation of the satellite signal in the solar spectrum: An overview. IEEE Transactions on Geoscience and Remote Sensing, 35(3), 675-686.

Viña, A., \& Gitelson, A. A. (2005). New developments in the remote estimation of the fraction of absorbed photosynthetically active radiation in crops. Geophysical Research Letters, 32, L17403, doi:10.1029/2005GL023647.

Viña, A., Gitelson, A. A., Nguy-Robertson, A. L., \& Peng, Y. (2011). Comparison of different vegetation indices for the remote assessment of green leaf area index of crops. Remote Sensing of Environment, doi:10.1016/j.rse.2011.08.010.

Whittaker, R. H., \& Marks, P. L. (1975). Methods of assessing terrestrial productivity. In H. Lieth, \& R. H. Whittaker (Eds.), Primary productivity of the biosphere. Ecological studies, 14. (pp. 55-118) : Springer-Verlag.

Wu, C., Chen, J. M., \& Huang, N. (2011). Predicting gross primary production from the enhanced vegetation index and photosynthetically active radiation: Evaluation and calibration. Remote Sensing of Environment, doi:10.1016/j.rse.2011.08.006.

Wu, C., Niu, Z., \& Gao, S. (2010a). Gross primary production estimation from MODIS data with vegetation index and photosynthetically active radiation in maize. Journal of Geophysical Research, 115, D12127, doi:10.1029/2009JD013023, 2010.

Wu, C., Niu, Z., Tang, Q., Huang, W., Rivard, B., \& Feng, J. (2009). Remote estimation of gross primary production in wheat using chlorophyll-related vegetation indices. Agricultural and Forest Meteorology, 149, 1015-1021.

Wu, C., Wang, L., Niu, Z., Gao, S., \& Wu, M. Q. (2010b). Nondestructive estimation of canopy chlorophyll content using Hyperion and Landsat/TM images. International Journal of Remote Sensing, 31(8), 2159-2167.

Xu, L., \& Baldocchi, D. D. (2003). Seasonal variation in carbon dioxide exchange over a Mediterranean annual grassland in California. Agricultural and Forest Meteorology, 123, 79-96.

Zhao, M., Heinsch, F. A., Nemani, R. R., \& Running, S. W. (2005). Improvement of the MODIS terrestrial gross and net primary production global data set. Remote Sensing of Environment, 95, 164-176. 